\title{
ANALISIS KUALITAS SENSORI IKAN ASAP BERBAHAN BAKAR BRIKET CAMPURAN (ARANG BONGGOL JAGUNG DAN DAUN JATI) DAN BAHAN BAKAR KAYU
}

\section{ANALYSIS OF THE SENSORY QUALITY OF SMOKED FISH FUELED BY MIXED BRIQUETTES (CORNCOB CHARCOAL AND TEAK LEAVES) AND WOOD FUEL}

\author{
Dwi Sukowati $^{1 *}$, Dwi Yanuar Budi Prasetyo ${ }^{1}$, dan Triat Adi Yuwono ${ }^{2}$ \\ ${ }^{1}$ Program Studi Ilmu Perikanan, Fakultas Sains dan Teknologi Universitas Nahdlatul Ulama Purwokerto, Indonesia \\ ${ }^{2}$ Program Studi Teknik Pertanian dan Biosistem, Fakultas Sains dan Teknologi Universitas Nahdlatul Ulama \\ Purwokerto, Indonesia \\ *Email: dwifisika25@gmail.com
}

Diterima: 17 Oktober 2020. Disetujui: 20 Oktober 2020. Dipublikasikan: 9 Januari 2021

\begin{abstract}
Abstrak: Penelitian ini bertujuan untuk menganalisis kualitas sensoris ikan asap menggunakan bahan bakar campuran briket (daun jati dan arang tongkol jagung) dengan perekat 5\% dan 10\% dan ikan asap menggunakan kayu bakar. Kayu yang digunakan sebagai pembanding adalah kayu mirah (tekstur lunak) dan mahoni (tekstur keras). Analisis sensorik dalam penelitian ini menekankan pada penampakan, warna, bau, rasa dan tekstur ikan asap. Untuk mengetahui ada tidaknya perbedaan yang signifikan dari keempat perlakuan tersebut terhadap hasil pengasapan ikan, penelitian ini menggunakan Analysis of Varians (Anova). Hasil penelitian menunjukkan bahwa terdapat perbedaan yang signifikan antara keempat metode pemberian pakan menggunakan briket dan bahan bakar kayu terhadap penampilan, warna, bau dan tekstur. Penampilan, warna dan aroma yang mendominasi spesifikasi ikan asap lainnya adalah ikan asap dengan perlakuan bahan bakar briket perekat 10\%. Tekstur ikan asap dengan bahan bakar kayu mahoni menunjukkan spesifikasi yang lebih baik dibandingkan ikan asap dengan perlakuan lainnya. Karena terdapat perbedaan yang signifikan maka dilakukan pengujian lanjutan dengan menggunakan Uji BNJ. Uji BNJ harus dilakukan untuk mengetahui hubungan pembeda antar sampel. Sedangkan pada uji rasa tidak ada perbedaan yang signifikan dengan perlakuan.
\end{abstract}

Kata Kunci: Briket, Ikan Asap, Analisis Sensori

\begin{abstract}
This study aims to analyze the sensory quality of smoked fish using mixed briquette fuel (teak leaves and corncob charcoal) with 5\% and 10\% adhesives with smoked fish using wood fuel. The wood used for comparison is Mirah (soft texture) and mahogany (hard texture). Sensory analysis in this study emphasizes the appearances, colors, smells, tastes and textures of smoked fish. To determine whether there is a significant difference or not of the four treatments on the results of smoking fish,this study use Analysis of Varians (Anova). The results showed that there were significant differences between the four methods of feeding fish using briquette and wood fuel on appearances, colors, smells and textures. The appearance, color and aroma that dominate the specifications of other smoked fish are smoked fish with $10 \%$ adhesive briquette fuel treatment. The texture of smoked fish with mahogany wood fuel shows better specifications than asp fish with other treatments. Because there is a significant difference, a further test is carried out using BNJ Test. BNJ Test must be done to find out the distinguishing relationship between samples. Whereas in the taste test, there was no significant difference from the treatments.
\end{abstract}

Keywords: Briquette; Smoked Fish; Analysis Sensory

\section{PENDAHULUAN}

Ikan asap merupakan salah satu produk olahan makanan yang disukai masyarakat karena aroma dan rasa yang khas. Metode fumigasi (pengasapan) ikan dapat dibagi menjadi dua metode pengsapan cair dan modern. Metode pengasapan cair memanfaatkan komponen utama dalam asap cair terdiri atas asam, derivat fenol, dan karbonil. Pengsapan cair memiliki keuntungan memperpanjang umur simpan ikan asap [1]. Sebagian masyarakat lebih menyukai hasil olahan makanan dari metode tradisional, dikarenakan kandungan asap yang berfungsi mengurangi kadar air ikan menambah aroma dan cita rasa yang khas [2]. Pengasapan dengan metode tradisional biasanya menggunakan bahan bakar kayu misalnya kayu mirah dan mahoni. Kedua kayu ini masih sering ditemui di daerah manaupun dengan harga relatif murah. Penggunaan kayu pada proses pengasapan menjadi hal yang umum, namun ada dampak yang akan timbul jika penggunaan kayu dilakukan secara berlebihan. Penebangan pohon untuk dijadikan bahan bahan bakar kayu dilakukan sebagian besar di derah pesisir Indonesia, bahkan pohon bakaupun tidak luput ditebang untuk memenuhi kebutuhan bahan bakar [3].

Limbah pengganti bahan bakar kayu dapat dimanfaatkan sebagai pengganti kayu. Salah satunya adalah briket limbah daun jati dan bonggol jagung. 
Daun jati memiliki potensi nilai kalor yang tinggi [4]. Nilai kalor briket daun jati dengan perekat kanji memiliki nilai kalor di atas $5000 \mathrm{kal} / \mathrm{g}^{3}$. Selain limbah daun jati, bonggol jagung juga masih menyimpan banyak manfaat yang belum dimanfaatkan secara maksimal. Penelitian sebelumnya telah meneliti karakteristik dan kualitas briket campuran daun jati dan arang bonggol jagung. Hasil penelitian menunjukan komposisi terbaik daun jati dan arang bonggol jagung dijadikan briket adalah 2:1 dengan persentase perekat 5\% dan $10 \%$ [5]. Hasil penelitian tersebut menjadi acuan penelitian ini dalam menganalisis perbandingan kualitas ikan asap menggunakan bahan bakar briket campuran (daun jati dan arang bonggol jagung) dengan bahan bakar kayu. Kayu yang digunakan sebagai pembanding memiliki kiteria kekerasan yang berbeda yaitu kayu mahoni dan kayu mirah. Kualitas ikan asap yang dianalisis adalah sensori/ organoleptic meliputi kenampakan, warna, aroma, rasa, dan tekstur.

Pengasapan merupakan salah satu metode pengawetan dengan memanfaatkan fungsi asap sebagai komponen penurun kadar air dan pemberi aroma khas pada produk hasil pengasapan. Pengasapan ikan memadukan dua komponen yaitu penggaraman dan pengeringan [6]. Ada beberapa metode pengasapan diantaranya metode pengasapan panas, pengasapan dingin dan asap cair [7]. Metode Pengasapan menggunakan bahan bakar kayu merupakan salah satu metode pengasapan panas. Suhu saat pengasapan ikan $\pm 70{ }^{\circ} \mathrm{C}$. Kriteria kayu yang digunakan biasanya lambat terbakar dan tekstur keras. Jika menggukan kayu lunak menghasilkan banyak asap, yang dapat menyebabkan poduk pengasapan menjadi hitam [8].

Penelitian lain terkait dengan penggunaan briket dalam pengasapan ikan adalah Pengasapan ikan bandeng dengan bahan bakar briket ampas tahu [9]. Bahan bakar briket ampas tebu menghasilkan jumlah asap yang paling banyak dan distribusi yang merata di dalam ruang pengasap. Kadar air, kadar abu, protein dan Kandungan lemak yang dihasilkan dari pengasapan ikan bandeng menggunakan briket ampas tahu berturu-turut adalah $58.3 \% ; 2.09 \% ; 25.64 \%$; $5.1 \%$. Pengujian sensori/ organoleptik meliputi kenampakan, bau, rasa dan tekstur dari pengasapan ikan bandeng menggunakan briket ampas tahu mendapat nilai 9 dimana secara fisik utuh, bersih dan memiliki warna coklat yang sangat mengkilat. Bau dari ikan asapnya memiliki aroma kurang harum dan rasa cenderung manis dan asin. Penelitian lainnya adalah pengujian kualitas ikan manyung asap dengan bahan bakar serabut kelapa [6]. Hasil uji organoleptik ikan manyung asap dengan selang kepercayaan $95 \%$ adalah $7.55 \leq \mu \leq 7.99$. Kandungan fenol, kadar air, dan indicator karsinogenik berturut-turut adalah $0,0225 \% ; 70,60 \% \pm 0,141 \% ; 0,0078 \mathrm{ppm}$.
Penelitian-penelitian yang telah dilakukan mempunyai perbedaan dengan penelitian ini yaitu pada perlakuan dengan bahan bakar kayu dan limbah yaitu briket campuran arang bonggol jagung dan daun jati). Penelitian ini menganalisis hasil uji sensori dari perlakuan tersebut meliputi kenampakan, warna, aroma, rasa, dan tekstur.

\section{METODE PENELITIAN}

Metode penelitian yang digunakan adalah metode eksperimen. Dimana terdapat empat perlakuan yang berbeda untuk mengetahui kualitas ikan asap. Perlakuan tersebut adalah penggunaan bahan bakar yang digunakan dalam pengasapan yaitu bahan bakar briket perekat $5 \%$, perekat $10 \%$, bahan bakar kayu mirah dan mahoni. Ikan yang digunakan dalam pengsapan adalah ikan tongkol dengan panjang sekitar $22 \mathrm{~cm}$. Prosedur pelaksanaan penelitian meliputi beberapa tahapan yaitu tahap persiapan, tahap pengujian dan terakhir tahap analisis data.

Tahap persiapan meliputi kegiatan membuat bahan bakar briket. Perbandingan arang bonggol jagung dan daun jati untuk kedua briket yang akan digunakan sama yaitu $2: 1$, hanya ada perbedaan variasi yaitu perekat kanji 5\% dan 10\% dari bahan utama. Persiapan selanjutnya adalah pemilahan kayu mirah dan mahoni. Kayu mirah dan mahoni di cacah sedemikian rupa agar tidak terlalu berbeda jauh volumenya dengan briket. Setelah semua bahan bakar terkumpul, proses selanjutnya adalah pengsapan ikan. Pengasapan ikan dilakukan dalam waktu yang sama yaitu 2 jam. Alat yang digunakan dalam pengsapan adalah tungku sebagai tempat bahan bakar dan ruang pengasapan sebagai tempat ikan.

Tahap kedua adalah pengujian. Pengujian sensori dilakukan oleh 20 responden. Uji sensori menggunakan nilai skala 1 hingga 9. Indikator tiap penilaian mengikuti Standarisasi dari Dikti. Tahap terakhir adalah analisis data. Analisis data yang digunakan adalah analisis varian untuk mengetahu ada tidaknya perbedaan yang signifikan. Jika ada perbedaan maka dilanjutkan dengan uji BNJ.

\section{HASIL DAN PEMBAHASAN}

Analisis organoleptik atau sensori dilakukan dengan melibatkan 20 responden. Untuk memudahkan dalam analisis data digunakan singkatan dari masing-masing perlakuan yaitu, IMI (Pengsapan ikan tongkol dengan kayu mirah); IMA (Pengasapan ikan tongkol dengan kayu mahoni); IB5 (Pengasapan ikan tongkol dengan briket perekat 5\%); IB1 (Pengasapan ikan tongkol dengan briket perekat 10\%).Responden menilai lima aspek dari masingmasing ikan asap yaitu kenampakan dan warna, aroma, rasa, tekstur. Skala penilaian yang digunakan mengikuti skala penilaian dari Standar Dikti tahun 2009. Adapun salah satu contoh penilaian dari responden seperti pada gambar 1 . 


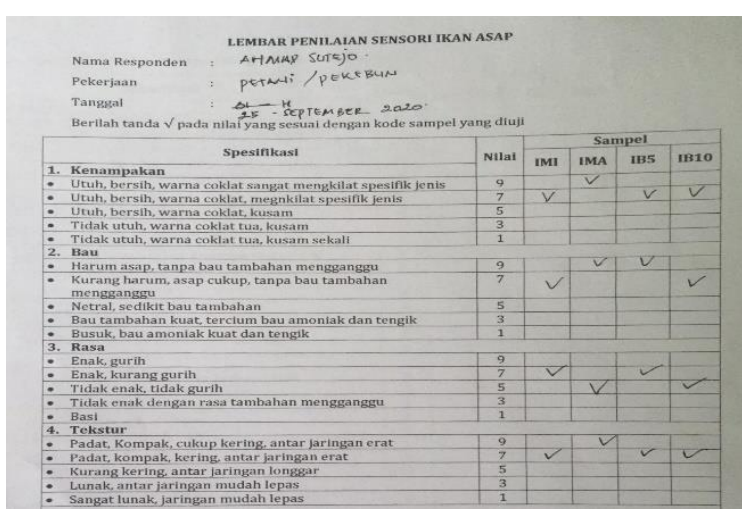

Gambar 1. Contoh penilaian dari responden

Penilaian responden yang telah dianalisis mengahasilkan nilai $\mathrm{F}_{\text {Tabel }}$ sebagai berikut:

Tabel 1. Hasil Analisis $\mathrm{F}_{\text {Hitung }}$

\begin{tabular}{|c|c|c|c|}
\hline \multirow{2}{*}{ Spesifikasi } & \multirow[t]{2}{*}{$\mathrm{F}_{\text {Hitung }}$} & \multicolumn{2}{|l|}{$\mathrm{F}_{\text {Tabel }}$} \\
\hline & & $5 \%$ & $1 \%$ \\
\hline Kenampakan \& warna & 7.24 & \multirow{4}{*}{3.16} & \multirow{4}{*}{5.01} \\
\hline Aroma & 8.82 & & \\
\hline Rasa & 1.13 & & \\
\hline Tekstur & 65.18 & & \\
\hline
\end{tabular}

\section{Kenampakan dan warna}

Pada tabel 1. Terlihat bahwa $\mathrm{F}_{\text {Hitung }}>\mathrm{F}_{\text {Tabel. }}$. Artinya ada perbedaan yang signifikan dari pemberian perlakuan dengan bahan bakar yang berbeda terhadap hasil pengasapan ikan. Sehingga dilakukan uji BNJ Kenampakan dan Warna. Dengan nilai Standar Error (SE) 0.28 diperoleh Shortest Significant ranges (Rp) pada taraf $5 \%$ sebesar $0.82 ; 0.86 ; 0.89$. Kemudian nilai Rp dibandingkan dengan selisih rata-rata sampel dari yang tertingi. Nilai rata-rata tiap perlakuan ditunjukkan pada tabel 2 .

Tabel 2. Nilai Rata-rata tiap Perlakuan

\begin{tabular}{lrrrr}
\hline \multirow{2}{*}{ Spesifikasi } & \multicolumn{3}{l}{ Perlakuan } & \\
\cline { 2 - 5 } & IMI & IMA & IB5 & IB10 \\
\hline Kenampakan \& warna & 4.2 & 5.2 & 5.1 & 6.3 \\
Aroma & 7.8 & 8 & 8.7 & 8.9 \\
Rasa & 6.4 & 6.5 & 6.7 & 6.8 \\
Tekstur & 7.7 & 8.6 & 6.4 & 7.2 \\
\hline
\end{tabular}

Pada Spesifikasi kenampakan dan warna IB10 memiliki rata-rata tertinggi. Hasilnya analisis lanjutan ini menunjukkan bahwa ada beda nyata pada perlakuan ikan asap dengan bahan bakar briket perekat $10 \%$ terhadap ikan asap dengan kayu mirah, kayu mahoni, briket $5 \%$ berturut-turut $2.10>0.89$; $1.20>0.86 ; 5.20>0.82$.

\section{Aroma}

Analisis aroma menggunakan anava menunjukkan bahwa $\mathrm{F}_{\text {Hitung }}>\mathrm{F}_{\text {Tabel. }}$ Artinya ada perbedaan signifikan terhadap perlakuan ikan asap menggunakan bahan bakar yang berbeda. Oleh karena perlu dilakukan uji lanjut. Dengan nilai Standar Error (SE) 0,18 diperoleh Shortest Significant ranges (Rp) pada taraf $5 \%$ sebesar $0.55 ; 0.58 ; 0.60$. Kemudian nilai Rp dibandingkan dengan selisih rata-rata sampel dari yang tertingi yaitu IB10. Hasilnya analisis lanjutan tersebut menunjukkan bahwa ada beda nyata aroma pada perlakuan ikan asap dengan bahan bakar briket perekat $10 \%$ terhadap ikan asap dengan bahan bakar kayu mirah dan kayu mahoni berturut-turut $1.10>$ $0.60 ; 0.90>0.58$. Tetapi tidak ada beda nyata aroma yang diuji antara ikan asap briket perekat $10 \%$ dengan briket perekat $5 \%$ yaitu $0.20<0.55$.

\section{Rasa}

Analisis uji terhadap rasa menunjukkan bahwa $\mathrm{F}_{\text {Hitung }}<\mathrm{F}_{\text {Tabel. }}$. Hal tersebut menunjukkan tidak ada pengaruh signifikan terhadap rasa ikan asap dari perlakuan menggunakan bahan bakar yang berbeda. Artinya, semua ikan asap hampir memiliki rasa yang sama tanpa ada rasa khas dari sampel ikan asap dengan bahan bakar tertentu. Sehingga tidak perlu dilakukan uji lanjutan.

\section{Tekstur}

Analisis uji terhadap tekstur ikan asap menunjukkan bahwa $\mathrm{F}_{\text {Hitung }}<\mathrm{F}_{\text {Tabel }}$. Artinya, ada pengaruh signifikan terhadap tekstur ikan asap dari perlakuan menggunakan bahan bakar yang berbeda. Oleh karena perlu dilakukan uji lanjut. Dengan nilai Standar Error (SE) 0,21 diperoleh Shortest Significant ranges $(\mathrm{Rp})$ pada taraf $5 \%$ sebesar $0.66 ; 0.64 ; 0.61$. Kemudian nilai Rp dibandingkan dengan selisih ratarata sampel dari yang tertinggi yaitu IMA. Hasil analisis lanjutan tersebut menunjukkan bahwa ada beda nyata tekstur pada perlakuan ikan asap dengan bahan bakar kayu mahoni terhadap ikan asap dengan bahan bakar briket perekat 5\% dan $10 \%$ (berturutturut $2.20>0.66 ; 1.40>0.64)$, tetapi tidak ada beda nyata tekstur yang diuji antara ikan asap bahan bakar kayu mahoni dengan kayu mirah yaitu $0.20<0.61$.

\section{Kenampakan dan Warna}

Ikan asap dengan bahan bakar briket $10 \%$ mempunyai kenampakan yang dominan lebih baik dibandingkan dengan yang lain. Dengan nilai rata-rata sampel 6,3. Menunjukkan bahwa kenampakan dapat dikatakan mendekati skala 7 yaitu utuh, bersih, warna mengkilat spesifika jenis. Kenampakan ikan asap dengan bahan bakar briket perekat $10 \%$ menunjukkan kondisi utuh, bersih, warna mengkilat spesifika jenis. Saat proses pengasapan, dari ke empat bahan bakar, api yang menyala dan asap yang dihasilkan lebih stabil adalah kayu mahoni dan briket perekat $10 \%$. Kayu mahoni merupakan kayu tekstur keras yang mudah terbakar, menghasilkan kalor yang tinggi sehingga cenderung lebih cepat mematangkan ikan asap. Warna ikan asap yang dihasilkan cenderung tidak memiliki warna coklat mengkilap. Untuk briket pada perekat 
$10 \%$ dari penelitian sebelumnya memiliki nilai kalor yang tinggi dan dalam 60 menit nyala api dan asap cenderung stabil. Untuk kayu mirah, warna ikan cenderung kusam karena asap yang dihasilkan sangat banyak tidak merata. Asap yang diserap oleh tubuh ikan bergantung pada jenis bahan bakar [10]. Lama waktu pengasapan juga mempengaruhi kenampakan dan warna ikan. Semakin lama waktu pengasapan akan memberikan kenampakan dan warna lebih baik [9].

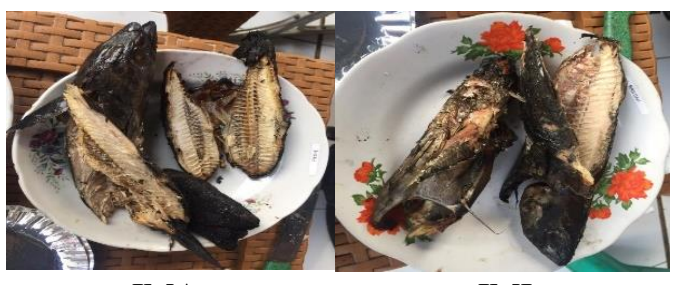

IMA IMI

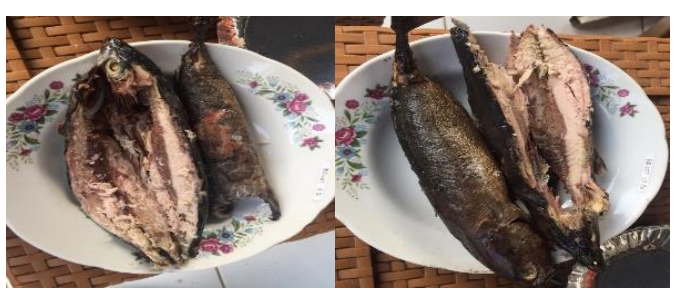

IB5

IB10

Gambar 2. Kenampakan dan warna ikan asap bagian dalam

\section{Aroma}

Ikan asap dengan bahan bakar briket $10 \%$ mempunyai aroma yang dominan harum asap tanpa ada aroma tambahan menggangu dibandingkan dengan yang lain. Nilai rata-rata sampel ikan asap dengan bahan bakar briket perekat $10 \%$ adalah 8.9. Aroma dipengaruhi oleh asap yang ditimbulkan dari bahan bakar. Asap yang terlalu menyebar banyak mengandung senyawa yang dapat menimbulkan hal dan bau tidak diinginkan [11]. Asap bahan bakar briket perekat $10 \%$ dan $5 \%$ jauh lebih stabil dibanding dengan bahan bakar lain.

\section{Rasa}

Rasa menjadi penentu konsumen dalam membeli suatu produk olahan. Perlakuan sebelum pengasapan dengan penggaraman dan juga proses curing akan berpengaruh terhadap rasa ikan asap yang dihasilkan [12]. Hasil analisis dalam penelitian ini tidak menunjukkan perbedaan yang signifikan dari empat perlakuan bahan bakar yang digunakan. Hal ini dikarenakan tidak ada perlakuan sebelum pengasapan seperti penggaraman atau Curing, sehingga dari responden merasakan hal yang sama antara ikan satu dengan yang lain.

\section{Tekstur}

Ikan asap dengan bahan bakar kayu mahoni mempunyai tekstur padat, kompak, cukup kering, antar jaringan kuat dibandingkan dengan ikan asap berbahan bakar briket. Nilai rata-rata sampel ikan asap dengan bahan bakar kayu mahoni adalah 8,6. Kayu mahoni dengan keunggulan tekstur lebih keras menghasilkan panas yang tinggi dengan asap tidak terlalu menyebar. Karakteristik ini membuat kematangan ikan jauh lebih cepat dan ikan lebih cepat keras dalam waktu pengasapan yang sama dengan bahan bakar lainnya. perbedaan nilai tekstur pada ikan asap juga dapat dikarenakan perbedaan kadar air dan jenis ikan.

\section{KESIMPULAN}

Penelitian ini menunjukkan bahwa ada pengaruh yang signifikan dari perlakuan pengunaan bahan bakar yang digunakan terhadap hasil sensori ikan asap. Pengaruh signifikan tersebut pada kenampakan dan warna, aroma, dan tekstur. Kenampakan, warna dan aroma yang mendominasi spesifikasi lebik baik dari ikan asap lain adalah ikan asap dengan perlakuan bahan bakar briket perekat $10 \%$. Tekstur ikan asap dengan bahan bakar kayu mahoni menunjukkan spesifikasi yang lebih baik dari ikan asp dengan perlakuan lainnya. Sedangkan pada uji rasa tida didapat perbedaan yang signifikan dari keempat perlakuan.

\section{DAFTAR PUSTAKA}

[1] Alçiçek, Z., Zencir, Ö., Çelik Çakiroğullari, G., \& Atar, H. H. (2010). The effect of liquid smoking of anchovy (Engraulis encrasicolus, L. 1758) fillets on sensory, meat yield, polycyclic aromatic hydrocarbon (PAH) content, and chemical changes. Journal of Aquatic Food Product Technology, 19(3-4), 264-273.

[2] Yanti, A.R., Rochima, E. (2009). Pengaruh Suhu Pengeringan Terhadap Karakteristik Kimiawi Fillet Lele Dumbo Asap Cair pada Penyimpanan Suhu Ruang. Jurnal Bionatura1. 1 (1), 21-36.

[3] Budaraga, I.K. (2018). The Effect of Combination of Liquid Smoke To Degrees of Material (PH) Fillet Fish Tilapia. International Journal of ChemTech Research. 11 (02), 207-217.

[4] Thoha, M.Y., Fajrin, D.E. (2010). Pembuatan Briket Arang dari Daun Jati dengan Sagu Aren sebagai Pengikat. Jurnal Teknik Kimia. 17 (1), 34-43.

[5] Sukowati, D., Yuwono, T.A., Nurhayati, A.D. (2019). Analisis Kualitas Briket Campuran Arang Bonggol Jagung dan Daun Jati. Musamus Journal of Science Education. 2 (1), 1-8.

[6] Ghazali, R.R., Swastawati, F., Romadhon. (2014). Analisa Tingkat Keamanan Ikan Manyung (Arius Thalassinus) Asap yang Diolah Dengan Metode Pengasapan Berbeda. Jurnal Pengolahan dan Bioteknologi Hasil Perikanan. 3 (4), 31-38.

[7] Susanto, E. (2014). Mempelajari Kinerja Alat Pengasap Ikan Tipe Cabinet dan Pengaruhnya 
terhadap Mutu Ikan Asap. Journal of Agro-based Industry. 31 (1), 32-38.

[8] Adeyeye, S.A.O., Oyewole, O.B. (2016). An Overview of Traditional Fish Smoking In Africa. Journal of Culinary Science \& Technology. 14 (3), 198-215.

[9] Nugroho, S.D., Soeparman S., Yuliati, L. (2018). Analisis Pengaruh Bahan Bakar Alternatif Pada Lemari Pengasap Ikan Terhadap Kualitas Produk Hasil Asapan. Jurnal Rekayasa Mesin. 9 (3), 191-200.

[10] Lombongadil G.P., Albert R.R., \& Hens, O. (2013). Studi Mutu Produk Ikan Japuh (Dussumieria acuta C.V.) Asap Kering Industri Rumah Tangga di Desa Tumpaan Baru, Kecamatan Tumpaan. Jurnal Media Teknologi Hasil Perikanan. 1 (2), 47-53.

[11]Darianto, Sitohang, H.T.S., Amrinsyah. (2018). Analisa Faktor-Faktor yang Mempengaruhi Proses Pengasapan Pada Mesin Pengasapan Ikan Lele. Journal of Mechanical Engineering, Manufactures, Materials and Energy. 2 (2), 5666.

[12] Mardiah, A., \& Fitria, E. A. (2018). Analisis Organoleptik Ikan Asap Yang Diolah Secara Tradisional. UNES Journal of Scientech Research, 3(2), 101-109. 